Additional services for Rural History:

Email alerts: Click here

Subscriptions: Click here

Commercial reprints: Click here

Terms of use : Click here

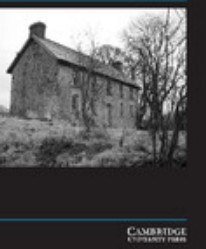

\title{
An Anti-Urban Education? Work Camps and Ideals of the Land in Interwar Britain
}

JOHN FIELD

Rural History / Volume 23 / Issue 02 / October 2012, pp 213 - 228

DOI: 10.1017/S0956793312000088, Published online: 17 September 2012

Link to this article: http://journals.cambridge.org/abstract_S0956793312000088

How to cite this article:

JOHN FIELD (2012). An Anti-Urban Education? Work Camps and Ideals of the Land in Interwar Britain. Rural History, 23, pp 213-228 doi:10.1017/S0956793312000088

Request Permissions : $\underline{\text { Click here }}$ 


\title{
An Anti-Urban Education? Work Camps and Ideals of the Land in Interwar Britain
}

\author{
J O H N F E L D \\ School of Education, University of Stirling, Stirling, FK9 4LA, UK \\ john.field@stir.ac.uk
}

\begin{abstract}
This article examines the role of work camp movements in developing rural critiques of urban living in interwar Britain. A variety of work camp movements flourished in Europe during the interwar years, often partly as a reaction against urbanisation, and this paper explores the ways in which three such movements developed the work camp as a means of countering the socialising influences of city life. Yet while all of the interwar British work camps were located in the countryside, they varied in the extent to which they tried to promote rural values and orientations among their trainees. We can see the work camp as a liminal pedagogic space, designed to lead trainees to particular educational outcomes, using techniques and methods that focused on bodily change as well as cognitive development.
\end{abstract}

The interwar years witnessed a remarkable explosion of movements to promote camping. Many were focussed on the young, for whom camping was believed to provide training for body and mind. By the early 1930s, the pedagogic case for youth camping was well understood. ${ }^{1}$ Thanks in large part to the success of scouting, its advocates could plausibly claim that camp life was not only intrinsically healthy, but helped to build character and leadership and foster citizenship, particularly for boys but among girls as well as. So widespread was the use of camping that teachers' manuals included instructions on how to get the most out of the annual school camp. ${ }^{2}$ Basil Henriques, a prominent youth worker, called it 'a platitude, but nevertheless true, that the week or ten days of camp are more important than the whole of the rest of the year put together'. Away from the 'artificial and often sordid surroundings' of everyday life, it was in camp 'that Friendship, Comradeship, Brotherhood and Fellowship are first learned', along with the skills of leadership and self-reliance' ${ }^{3}$

Public health arguments also formed an important element in the case for camping, particularly in the early years. This was part of a wider impulse to reintroduce children to lost elements of the natural, through heavily controlled spaces such as open-air schools, playing fields and swimming pools. ${ }^{4}$ Such arguments won a wider hearing after the First World War, in a context where renewed anxieties about the male body were used by Lloyd George to argue for stronger state policies on health, with the widely copied phrase, 'You cannot maintain an A1 Empire with a C3 population'. 5 Against a background of Bolshevism abroad and class conflict at home, the Duke of York sponsored a camping 
movement as a way of bringing together public school and state school boys, supported by the Industrial Welfare Society, and was filmed visiting the camps dressed in the contemporary hiker's uniform of shorts and an open shirt. ${ }^{6}$ Space, and rural space in particular, provided both a location and a means of instruction, as well as a yardstick against which to measure urban life, performing a multifaceted role in the construction of both youth and nature. ${ }^{7}$

The importance of camping and outdoor activities for children was therefore well established within pedagogic thought. So although the work camp systems were relatively new in the 1930s and were not aimed at children, they resembled youth camps in that they offered bounded and temporary accommodation, along with a time limited pedagogic experience of labouring in the outdoors. These liminal features suggested that their inmates were being emancipated from existing bonds and habits, but were also to acquire new dispositions and capacities as a result of their interactions with nature, with one another, and with the camp leaders. ${ }^{8}$

To explore these liminal and spatial dimensions, this paper concentrates on three case studies of movements in Britain in the 1930s: the government's Instructional Centres for long term unemployed men; the utopian communities of the Grith Fyrd movement; and English national education through work camps as developed and practised by Rolf Gardiner. The spatial dimension was significant in all three. All of these movements were bounded but liminal communities of instruction. Their location was invariably rural, and their primary means of instruction, namely work, was also inherently rural in character. It is in these senses that work camps were conceived by some of their advocates as exercises in an anti-urban education. Whether they also promoted a turn towards the rural is, however, another matter.

\section{Ministry of Labour Instructional Centres}

By far the most extensive work camp system in Britain was the Instructional Centre scheme. Managed by the Ministry of Labour, it comprised a varying number of mostly hutted but sometimes tented camps, where it sought to provide a three month course of heavy labour for young unemployed men. At its peak, in 1937, the scheme comprised some thirty camps, scattered across Britain's more remote areas and by 1939, roughly 200,000 men had spent time at an Instructional Centre, the vast majority of whom remained unemployed at the end. This was an intensely pragmatic scheme. Its origins lay in the mid 1920s, when the British government opened a small number of residential farm training centres, with the aim of preparing young unemployed men to emigrate to Australia and Canada. ${ }^{9}$ This policy had both geo-strategic and more domestic goals: as the Overseas Settlement Committee reflected, while the main 'object of Empire settlement is to distribute the white population of the British Commonwealth in the most efficient manner', the policy was also used 'so far as possible to find openings in other parts of the Empire for those who cannot find work at home'. ${ }^{10}$ When this programme came to an end in the late 1920s, the Ministry of Labour took the centres over, planning to use them as part of its wider strategy for labour transference. Its target was particularly young men who had been unemployed for some time, and had become "so "soft" and 
temporarily demoralised' that they could not be encouraged to move elsewhere 'until they are hardened'. ${ }^{11}$

In 1929 the incoming Labour Government adopted this proposal with some enthusiasm. The Labour Party had attacked the Conservatives for some years for their failure to rescue the long term unemployed, particularly in the mining areas, and a discourse of degeneration was common. In 1927, one Labour Member of Parliament complained that the unemployed were suffering a 'loss of dignity and virility' along with 'losses in character', while another stated that 'the so-called dole' was so inadequate that it was leading to serious 'physical deterioration'. ${ }^{12}$ George Lansbury, still a major presence in the Party, had been active in the labour colony movement in the 1890s, and had been centrally involved in attempts to train unemployed Londoners for a life on the land through the labour colonies at Laindon and Hollesley Bay. ${ }^{13}$ Lansbury was among a group of Labour Members of Parliament who continued to defend land settlement for the unemployed throughout the $1920 \mathrm{~s} .{ }^{14}$ Meanwhile, the socialist intellectual G. D. H. Cole called publicly for a National Labour Corps, combining health benefits for the unemployed with public works for the community, through 'roughing it' in camps. ${ }^{15}$

The relationship of all this with anti-urbanism was, however, complex. In contrast with previous crises over unemployment and poverty, the unemployment campaigners of the interwar years were concerned not about conditions among the urban population, but with the predicament of what became known as the 'distressed areas', such as the coalfields, where old industries had all but vanished as major sources of employment. Margaret Bondfield, Minister of Labour in the Labour Government, never expressed any interest in the Instructional Centres as a means of reducing the urban population. Nor did the Ministry of Labour at any stage make anti-urban thinking part of its case for the Instructional Centres programme. Their main interest lay in what they saw as the physical and moral deterioration of the long term unemployed and the location of the camps was selected with considerable forethought and care.

There were three major reasons for the location of the Instructional Centres. First, most were on or close to land that had been acquired for afforestation. This meant a plentiful supply of meaningful work, preparing vast estates of rough scrub and pasture so that the foresters could move in. And the work was not only meaningful but also heavy. As the Ministry put it, the 'training' mostly comprised 'hard manual labour, e.g. felling, grubbing roots, clearing scrub land, quarrying and road making'. ${ }^{16}$ There were also financial benefits, as the government had already acquired the land, and the Forestry Commission was able to share the costs. This was essentially a pragmatic justification for siting camps in rural areas. Second, officials believed that the location removed men from undesirable influences. This was essentially an efficiency argument, for an internal report argues that 'the progress of re-conditioning will be quicker and more effective if carried out away from the distressed areas, so that men live away from the depressing atmosphere of the coalfields'. ${ }^{17}$ The Ministry actively sought to maintain this barrier to social decay. In 1934, Mr Greenwood, manager of Ardentinny Instructional Centre, attended the Cowal Licensing Court to oppose the granting of a license to the local temperance hotel, saying that the absence of a public house was the 'chief attraction, so far as their scheme was concerned', and that a licensed house 'would be a temptation to the lads and might 
spoil their chances of getting employment'. ${ }^{18}$ Again, this was essentially a pragmatic, and indeed negative, strategy.

The third factor behind the choice of location was that it should allow for considerable standardisation and control. The Instructional Centres were all laid out along similar lines, with huts or tents grouped around a central area, over which flew the Union Flag. While they were not closed institutions, and locals sometimes complained that girls got in and men got out far too frequently for their liking, nonetheless the perimeter was marked by a fence and the entrance by a sign announcing its status as a Government Instructional Centre. Management structures were also standardised, as were the daily routine, diet and, from 1933, the disciplinary measures applied to offenders. After the Ministry put an end to localised systems of fines, these were effectively limited to the threat of expulsion or prosecution. Trainees were also issued with standardised clothing, although it was up to them whether they wore it. The Ministry allowed some local discretion to managers in respect of leisure and educational activities, but few went as far as the manager at Hamsterley, who woke his trainees up at 6.30 to the strains of 'hot jazz'. ${ }^{19}$ Privacy was almost completely absent, with twenty men sleeping in each hut and sharing the washing and toilet facilities.

In official discussions, the rural-urban continuum barely surfaced. In the early years, most recruits came from the coalfields. They were therefore often used to village and small town life, although they tended to find camp life boring after the first few days. Only later did recruitment extend to the cities, and then only to those with the highest unemployment levels. This occasionally presented the authorities with a challenge, above all in the case of Glasgow, which was identified in 1932 as the main area of recruitment for a new camp near the west coast, at Glenbranter. Initially, the Ministry's director of training thought Glasgow's unemployed 'would be glad of the opportunity of reconditioning in what is, in the summer time, a very attractive part of Scotland' ${ }^{20}$ Local officials quickly warned him that Glenbranter might be cut off for ' 3 or 4 of the winter months', ${ }^{21}$ while in summer the men would be eaten alive by midges. ${ }^{22}$ By the time the camp opened, the director of training had realised that he had no idea 'how unemployed men in Glasgow would react to the suggestion that they should spend three months in Argyllshire'. ${ }^{23} \mathrm{He}$ was also worried that he could not find a suitable Scot to appoint as camp manager.

Organisationally, the Instructional Centres scheme was closer to the Reichsarbeitsdienst than any other British initiative. Yet the differences are marked: participation was generally voluntary, if constrained; there was no explicit militaristic element and the men did not parade publicly; and it lacked the elaborate politico-pedagogic underpinning that Eugen Rosenstock-Huessy and Konstantin Hierl brought to the Reichsarbeitsdienst. Nor was there in Britain the interest in nature and rural communitarianism that underpinned Hierl's emphasis on farming, soldiering, Heimatkunde such as archaeology and völkisch cultural practices more generally. There was also a lot more smoking and drinking in the Instructional Centres. ${ }^{24}$

In contrast to the German model, the British scheme had what might be seen as a 'thin pedagogy', which valued hard labour, outdoor conditions and a plentiful diet as ways of reconditioning tired bodies. Richard Williams, the handkerchief manufacturer and poet who chaired the Unemployment Assistance Board for Northern Ireland, believed that 
'nothing brings a man more quickly into a condition of moral and physical fitness than open-air work under proper conditions' ${ }^{25}$ One British Fascist bitterly complained of the Ministry of Labour's timidity, contrasting the splendid physique of young Germans with the 'doomed' race of his own island:

At the present time the average Briton is a weak specimen, undersized and under-developed. His teeth are bad, his eyesight is none too good and is steadily growing worse.... The most alarming thing of all is the permanent state of semi-starvation under which half our people are forced to live. ${ }^{26}$

This writer saw the solution in a 'corporate state', while his party's policy was for boys and girls to perform a year's labour service, working 'in healthy surroundings for their keep and pocket money, to return at the end of that time to follow their own work of life with a new understanding of the lives of others ${ }^{27}$. Ironically, this was remarkably similar to Cole's proposal for a National Labour Corps.

Compared with the Reichsarbeitsdienst, as well as with Roosevelt's Civilian Conservation Corps, the Instructional Centres scheme was relatively small, piecemeal, and lacked any sustained ideological underpinning. Its authors were broadly concerned with physical decline and moral weakness, but attributed these to the experience of sustained unemployment and a poor diet, rather than to the urban and financial bias of western civilisation. Policy makers, particularly those associated with the Labour and Conservative parties, were sceptical of anti-urban rhetoric and downright hostile to schemes for rural resettlement, which they saw as economically foolish and socially regressive. The Instructional Centres scheme is, then, best understood as a largely pragmatic initiative, mounted on a relatively small scale, and designed to promote labour mobility without any regard to the rural/urban balance.

\section{Grith Fyrd}

If mainstream British policy circles were largely indifferent to ruralism, a significant fringe of smaller movements continued to lament the urbanisation of British society. While most belonged to the political Right, there was also a 'back to the land' tradition on the Left, often associated with radical forms of communitarianism. Anarchists, socialists and feminists had all founded a plethora of alternative communities in the late nineteenth century, drawing inspiration and guidance from a diverse set of critical thinkers including Leo Tolstoy, Edward Carpenter, William Morris and Alfred Russel Wallace. ${ }^{28}$ While few of the communities survived the century, the ideas continued to attract radicals disenchanted with the modern industrial world, a handful of whom turned their hands to practical community building.

Grith Fyrd, founded in 1931, was a radical English group with roots in the Woodcraft youth movement. ${ }^{29}$ Its founders saw it as much more than an unemployment scheme: its ambition was no less than restoration of the values and strengths of the traditional English yeomanry. By building rural communities and developing the 'pioneer spirit', Grith Fyrd presented itself as shedding the artificial constraints and conformity of an urban, industrial Britain that was on the verge of collapse. While it appealed to the 
unemployed, it set out to meet, according to Jimmy Mallon, warden of Toynbee Hall, 'needs which would exist even if there were no unemployment'. ${ }^{30}$ It planned a number of camps across England, each serving as the first step in a three-stage process. The camps were followed by a lengthy tour of England on foot, reminiscent of the travels of medieval journeymen, and the process concluded with a substantial period of social service, spent on coastal reclamation, archaeological excavations or organising children's camps.

Grith Fyrd's first camp was built on land belonging to the Westlake family, at Sandy Balls, a mile or so east of the small Hampshire town of Fordingbridge on the northern edge of the New Forest. Ernest Westlake, an amateur naturalist and geologist, and founder of the Order of Woodcraft Chivalry, had originally planned to use the site for a Forest School. After he was killed in a road accident in 1922, his son Aubrey took forward the plans for a Forest School, which duly opened at Sandy Balls in two wooden buildings in 1929 . Sandy Balls was home for many of the Order of Woodcraft Chivalry's activities. These, according to Aubrey Westlake, consisted partly of organised social activities such as folk singing, country dancing, sports, archery contests and various ceremonies, and partly of business sessions, where the Order debated such matters as 'gymnosophy' (naturism) and sun-bathing. ${ }^{31}$ The group also had links with Rolf Gardiner, who as an undergraduate at Cambridge had edited a magazine called Youth; in 1925 he was invited to Sandy Balls, addressing the Order's Folkmoot on the subject of European Youth Movements, which provided him with an opportunity to praise the German Wandervögel. ${ }^{32}$ Some of the Order of Woodcraft Chivalry's members later joined him at a Freischar work camp in Silesia ${ }^{33}$.

In the following year, Westlake called a summer camp and conference to consider a massive project of land settlement and communal living. He originally called this idea Ephebe, a classical Greek word for a ritualised process of training young men for citizenship and military service. For the Westlakes, these ideas were closely bound up with notions of virility, strength and community. Speaking at the 1926 Folkmoot, Westlake proposed that Ephebe should be a three-year scheme involving 'physical training in athletics, sports, nude culture, military training to the extent of teaching everyone to shoot . . . camping, trekking', ending with voluntary community work. ${ }^{34}$ Encouraged by the psychiatrist Norman Glaister, the 1931 Order of Woodcraft Chivalry folkmoot agreed to launch the scheme. Glaister spoke of a series of camps around the country, each with sixty or so men, who would produce their own food, clothing and other requirements, trading under a barter system. ${ }^{35}$ Training would last for eighteen months, six of which would be spent in camp, six on travel elsewhere in Britain, and six on uneconomic but desirable work. Westlake thought women would also join the scheme, serving as 'hostesses to the men'. ${ }^{36}$ After discussion, Westlake tried anglicising Ephebe as 'FEB', but in 1932 the Order chose what it saw as a more defensible name for its scheme. The name 'Grith Fyrd', usually translated from the Anglo Saxon as 'Peace Army', was Glaister and Westlake's way of establishing their movement as unambiguously English.

Grith Fyrd camps were intended as an exercise in community building, under challenging conditions. The first was opened in March 1932, when six young unemployed men set about building a log cabin in Godshill, in the New Forest. All unemployed, they came from a variety of social backgrounds: an ex-accountant, a cabinet-maker, two laboratory assistants, a Morris dance instructor and an engineer. ${ }^{37}$ After chopping down 
thirty pine trees, they achieved their task in a week, and were joined by twenty more young men before building a second bunkhouse. Following the bunkhouses, which were originally hessian-sided and roofed with tarpaulin, they then built an eating house, roofed and clad in reeds cut from the nearby river bank, and a clay oven, and made a rough road from oak and larch. ${ }^{38}$ By September, twenty-five young men were living in wooden huts, preparing for the winter. The movement opened its second camp in 1934, at Shining Cliff Woods in Derbyshire. ${ }^{39}$ By 1937, it had also acquired a small estate of thirty-five acres at Brede, in Sussex, where it settled half a dozen men 'who have proved themselves in our camps', with a view to becoming the first of Grith Fyrd's self-sufficient cooperative communities. ${ }^{40}$

There is a clear anti-urban element in the thinking of the Grith Fyrd leadership. But it was subordinated to a variety of other mobilising passions, the first of which was pacifism. Westlake, Glaister and other Grith Fyrd leaders viewed the First World War with horror, seeing it as the perverted outcome of humanity's quest for challenges to overcome. In a paper written in 1931, Westlake spoke of Ephebe as 'a true and real alternative to militarism, possessing all the positive military virtues' and giving 'scope for hardihood and heroism'. It should also 'develop the group life, its loyalty and patriotism . . . as well as a sympathetic understanding of other nations' ${ }^{41}$ Even in a paper for the hard-headed economists of the Treasury, Grith Fyrd's leaders could not resist painting itself as mobilising 'some of the spirit of adventure which not only sustains pioneers in the pressing ordeals of primitive conditions, but cultivates the endurance needed for any kind of successful economic settlement ${ }^{\prime 42}$.

The movement's thinking on adventure was clearly gendered. Its aim, wrote Norman Glaister, was to provide a substitute that was 'great enough to captivate young men no less than they have been captivated by the glories of war'. ${ }^{43}$ The harder the work, the better, and Glaister and Westlake both publicly celebrated what they called the 'primitive' and 'pioneering' aspects of camp life, as a way of attracting men and building manhood. Aubrey Westlake described the camps' recruits as 'only half men', who had 'developed on one track, their trade', at a time when workers were being replaced by machines. The constructive use of often enforced leisure was an increasing problem. He accordingly saw the camps as a way of developing men's 'spiritual and athletic powers, in addition to supplying their own simple needs' ${ }^{44}$. For Westlake and Glaister, therefore, the rural and wooded locations of Shining Hill and Sandy Balls represented more than a convenient environment. In positive terms, they offered both 'a method and a technique whereby men and women can adapt themselves to a full rural life which is based on a spirit of pioneering and presses on towards self-support'. It was training 'able leaders' through 'a permanent system of selective adjustment under pioneering conditions'. ${ }^{45}$ From the movement's perspective, an upper limit of fifty men per camp meant that each was a community, 'a social unit in which every man has his own place and value'. ${ }^{46}$

At its peak, Grith Fyrd attracted enormous attention. The novelist Aldous Huxley visited Godshill, and was greatly impressed with the potential of what he saw. ${ }^{47}$ The BBC broadcast a programme from the camp, and it was filmed for the Pathé News. It sought to build links with the women's movement and the labour movement, particularly through the Workers' Educational Association, which ran classes at Godshill. ${ }^{48}$ It lobbied 
government departments for support with some success, ${ }^{49}$ but it is probably no great surprise that the movement fell into decline once unemployment started to fall. Yet it did not disappear and had a limited influence on later thinking and practice respecting residential therapeutic communities, not least as a result of its impact on outward bound treatments through the Hawkspur experiment. ${ }^{50}$ Its influence also led indirectly to the foundation of Braziers, a residential adult college community founded by Norman Glaister and Glynn Faithfull. Its connection with the Woodcraft movement and its associated youth groups meant that many of its core ideas, of adventure as a remedy for urban complacency and lived community as a remedy for individualism, have had a continuing, if limited, appeal.

\section{Cleveland and the Springhead Ring}

Grith Fyrd's political home was on the Left, but more characteristically, British antiurbanism has belonged to the political Right. This was particularly so in the case of Rolf Gardiner, a poet, folklorist, nudist, forester and farmer, whose reputation has been dogged by persistent and substantiated accusations that he was at least a Nazi sympathiser, if not potentially a willing collaborator and organiser of a peculiarly British Nazism. ${ }^{51}$ London born, he was brought up largely in Berlin. On returning to Britain, he joined the Boy Scouts, and although he found that experience disappointing, he pursued his interest in youth movements, including John Hargrave's breakaway primitivist group, the Kibbo Kift Kindred, which soon proved insufficiently nationalist for his liking. ${ }^{52}$ Gardiner threw himself into building ties with the German youth movement, particularly the Wandervögel and, inspired by his hero and friend D. H. Lawrence, he became preoccupied with 'reviving' English traditional dance, which he represented as a particularly masculine form. ${ }^{53}$ Gardiner can therefore be seen as a British example of the völkisch ideology that had such a profound impact on the Nazi movement and seemed rather quaint, if not bizarre, in a British context.

Gardiner, despite admiring the cultural tastes of Grith Fyrd, thought them slackers. In his view, in Grith Fyrd and other British forms of voluntary work service 'the tempo of work has been far too slack and easy'. ${ }^{4}$ Unlike Gardiner's own camps, the movement was simply not 'virile'. Gardiner organised a number of work camp movements in Britain, inspired by what he understood of the voluntary labour service movement in Weimar Germany. In 1927, he joined an Arbeitslager on Lüneberg Heath organised by the Deutsche Freischar, at which he choreographed a naked 'serpentine dance', to be performed by the campers daily after reveille at $5.45 \mathrm{am} .{ }^{55}$ Subsequently, he organised work camps for students and unemployed miners at Boosbeck, in the Cleveland Hills of North Yorkshire, as part of a local landowner's attempt to develop rural industries alongside the ironstone mines of the region. He also held a number of harvest camps on his family's farms at Gore and Springhead in Dorset, where he increasingly focused his activities for the circle of friends, sympathisers and like-minded men and women whom he later named the Springhead Ring.

Gardiner had a well established concern with social and cultural activities as expressions of 'the life-quality'. Greatly interested in English traditional music and dance 
himself, he actively encouraged the students and miners in Cleveland to come together in the afternoons and evenings. The students played football against local village teams. At Gore Farm in 1930, Gardiner arranged a 'spud fight' with local scouts and spent an evening with the Club's members, leading another sing-song around the camp fire. ${ }^{56} \mathrm{He}$ also had the Lingfield miners present a North Yorkshire sword dance, and the whole group spent three days hiking, with a 'flag-raiding contest' between Scots and English as the grand finale. ${ }^{57}$ Down in Dorset, Gardiner encouraged a group of unemployed miners and students, drawn from both Britain and Germany, to perform a dramatised version of a medieval ballad arranged by the poet Christopher Scaife. At the Springhead harvest camps, work groups sang while marching, the orderlies sang during the evening meal, and at night the campers sang in a choir. ${ }^{58}$

Much as he venerated the ancient ways, Gardiner was equally happy to invent new traditions. He believed that true work camps required 'forms which emphasise the community in relation to its surroundings and its task', helping produce 'order, reverence, comradeship'. At Springhead, the campers awoke to the rhythmic beating of a ceremonial gong, and paraded before the flagstaff before breakfast. In the evenings, they linked arms in a ring in the farm courtyard, lit only by single torch, and sang:

The earth has turned us from the sun,

And let us close our circle now to light,

But open it to darkness, and each one

Warm with this circle's warming,

Go in good darkness to good sleep,

Good night. ${ }^{59}$

According to one informant, Gardiner combined sun-worship (nudism) with 'disgusting practices under the influence of hypnotism', but the security services thought this salacious rural speculation. ${ }^{60}$

Gardiner had a strongly developed sense of physicality. ${ }^{61}$ While he greatly admired the naturism of some German youth movements, he extended his interest in the body, particularly the male body, to traditional art forms. His love of folk dance was one way of expressing his ideal of the strong male body as bearer of a national culture. $\mathrm{He}$ celebrated Morris dancing in one of his early poems as 'A rebirth of remote experience' and a form of 'pure religion', urging the dance to 'Cleanse us, O spirit, England's heartbeat throbbing! ${ }^{62}$ He described sword and Morris dancing sides together as a kind of Blutbruderschaft and in the same essay, published in Dresden in 1923, he singled out sword dancing as epitomising an ideal of 'perfect co-operation', where individuals together formed 'a man of superhuman power'. ${ }^{63}$ These themes were to preoccupy Gardiner throughout his long search for an authentic English and North European cultural nationalism.

Along with cultural and physical activities, Gardiner insisted that at least four hours daily should be devoted to work. Work, for Gardiner, had a mystical value. The basis of any true work camp, he wrote, 'is religious in the direct sense of the term: it apportions to each and all physical, intellectual and emotional exercise' ${ }^{64}$ Gardiner's general view, as expressed in a conference on student voluntary service, was that the work camp provided 
'an answer of the European spirit to the mechanising and standardising of all social and economic processes'. Its purpose was 'to wrest creative toil from the inexorable mechanism of the financial system', to 'root labour once again in the soil, to restore to work its lost homeland'. ${ }^{65}$ A fluent German speaker, Gardiner was well aware of the strongly positive associations of the term 'homeland' (Heimat) to delegates from the Nazi youth movement. But this was more than a hand across the North Sea: like many in the Reichsarbeitsdienst, Gardiner believed that honest labour, on the land, would provide an antidote to the artificial, money-based social relationships of industrial capitalism. Indeed, this was precisely how Konstantin Hierl presented the role of the Reichsarbeitsdienst in training up a 'new, National Socialist Man'. ${ }^{66}$

Work, for Gardiner, was valuable in its own right. He had 'no doubt that the compelling discipline of really slogging work and alacrity in every form are urgently required by the young men of Britain, many of whom are losing or have never acquired the habit of strenuous labour'. But he also painted work as a way of creating a sense of masculine identity: 'A virile form is an absolute necessity for young men. Only by pitching together against difficulties or hardship does comradeship grow'. ${ }^{67}$ He emphasised the need to bring the unemployed and the students together in 'an experimental form of social university' and even described this as 'the next step forward in national education'. ${ }^{68}$ Gardiner's commitment to fellowship reached out over national borders. The clue to his internationalism was clearly signalled by the title of the small journal that he edited, and largely wrote, for a small group of like-minded sympathisers and friends: North Sea and Baltic. He spoke admiringly of Cleveland as 'populated by a people of robust Scandinavian stock', ${ }^{69}$ and thought it 'fortunate that many of the unemployed are of good agricultural stock, and have not been separated from the soil for more than a generation' ${ }^{70}$ Further south, he claimed 'The old Saxon, Germanic bonds that held Wessex in King Alfred's and Canute's days have been twisted afresh round Gore'. ${ }^{71}$ And to some extent, this was reciprocated. Otto Bene thought the 1934 camp, while amateur by German standards, was 'well above the average English one', and urged the Nazi Party's Auslandsorganisation to give Gardiner their support. ${ }^{72}$

Finally, Gardiner increasingly saw the camps as a way of developing leadership in a Britain that had gone flabby. He admired the Danish adult educator and pastor Nicolaj Grundtvig, founder of the Folk High Schools, for his contribution to combining leadership development with national education. ${ }^{73}$ In 1933, Gardiner set out his plans for a 'rural university', taking the Danish Folkehøjskoler as his ultimate model, but in the mean time proposing a series of 'short work camps' ${ }^{74}$ In a later paper much influenced by his encounters with the Danish folk high school movement, Gardiner set out his plans for 'a residential centre for social education' at his farm. Its purpose, he wrote:

Is to give young men between the ages of 18-25 an experience of community life which will fit them for cultural initiative in the many new Social units arising as a result of schemes evolved to meet unemployment and increased leisure. ${ }^{75}$

By the time that Gardiner was advertising places at the Springhead camps, he specified that he hoped to recruit men who are 'the potential leaders of tomorrow' ${ }^{76}$ With a system of work camps and Danish Folk High Schools, the unemployed man might become 'the 
potential bearer of a new order of society'. ${ }^{77}$ What that society would involve was not entirely clear, but it was to be based on the land, governed on a regional basis, inspired by strong leaders, and utterly English. As he put it in 1939, 'We have got to restore and remake the real England which is basically that rural England upon whose final destruction the forces of today are willy-nilly bent'. ${ }^{78}$ Gardiner did not spell out precisely what these dark 'forces' might be, although it is clear that he blamed Jews among others. In 1938 he bewailed the impact on England of 'The forces of darkness, expressed in chaotic thought, vulgar emotion, widespread unreliability and incompetence, and in deliberate misinformation by our Jew-controlled press, cinema, wireless and advertising' ${ }^{79}$ There can be little doubt that his was a racially based view of Englishness, albeit one that he believed required constant nurturing through physical and cultural work. Fundamentally, he is best understood as an organicist thinker, whose ambition was 'to restore the pattern of rural England and to train a new generation for ploughing the difficult glebe of the future' ${ }^{80}$

Gardiner attracted some attention during the 1930s, although not nearly as much as Grith Fyrd. His völkisch concern for traditional dance and song had several strange consequences, one of which was the recruitment of a youthful Michael Tippett to join the Cleveland camp. The communist composer stayed on in the area, living over a shop in Boosbeck for about a year, and working on a new opera about Robin Hood (another figure from the forests), duly performed by a cast of miners in a church hall in the following year. ${ }^{81}$ He also persuaded the writer David Ayerst, a close friend of W. H. Auden and one-time secretary of the Oxford University Labour Club, and the poet Christopher Scaife to help organise camps. As shown above, he had good connections with Grith Fyrd itself, as well as with others in the Woodcraft movement and he had influential allies in Germany and Denmark. He appears to have been reasonably well acquainted with Otto Bene, the Nazi Party's Landesgruppenleiter for Britain and Ireland, and the British security service described him as 'an intimate friend' of the youth leader Baldur von Schirach, the bisexual head of the Hitlerjugend. ${ }^{82}$ However, his German allegiances were double-edged, ensuring him the continued attention of the security forces, and apparently costing him the support, and Cleveland land, of Major Pennyman.

All this changed in 1939. Gardiner had a continuing influence after the War, primarily through his work as a thinker and practitioner of organic farming. ${ }^{83} \mathrm{He}$ also sought to modernise farming in Nyasaland (now Malawi), attracting the continuing interest of the security forces who suspected him of providing a safe haven for Germans fleeing justice after the War. ${ }^{84}$ His farm survives as a residential centre for sustainable farming and creative living, offering a range of activities from eco-friendly accommodation to ponddipping. ${ }^{85}$ His account of the relationships between work, nature, music and dance, race and body culture as part of a 'national education' was highly distinctive, but he was widely dismissed during his lifetime as a 'crank' at best and Nazi at worst, and attempts to revive his reputation have had limited success.

\section{Conclusions}

Work camps, viewed as a type of anti-urban movement, represent a very specific form of outdoor education. They demanded a high level of commitment from participants 
and by their nature appealed mainly to youth and young adults. There was a marked gender dimension since virtually all work camp movements in Britain were aimed primarily at men. And while they were located in rural areas, there appears to have been a particular affinity with forest sites, whether for symbolic reasons or for more pragmatic purposes. Seen in a comparative perspective, they were under developed by the standards of Canadian, American, German and Scandinavian work camp initiatives. ${ }^{86}$ While the educational ideas behind them were relatively untheoretical in Britain, some of their advocates and organisers expressed clearly articulated educational ideas. It is also possible to identify specific methods of 'instructing' bodies and minds through the use of highly intensive manual labour.

Core to these practices was the idea of the work camp as an antidote to the malignant influences of contemporary British life. In two cases, this was explicitly defined as an anti-urban, pro-rural movement. In the case of Grith Fyrd, the camps were inspired by a diagnosis of the ills of industrialised society; the transition from rural to urban life had robbed humanity of its experiences of adventure, and the abilities to cope with them. The crisis of capitalist industry had endowed people with the leisure to rediscover their common humanity through planned adventure. Gardiner's thinking also placed the camps at the heart of a critique of contemporary British society, seeing camping and work as ways of rediscovering the 'virility' of the ancient Germanic and Nordic cultures and races of the British Isles. But while Grith Fyrd saw its camps as prefiguring and building the new society, Gardiner's 'national education' was concerned with preparing the leaders of a future virile England.

By contrast, the Ministry of Labour's scheme was bereft of any wider ideology or scheme for social transformation. This should be no surprise since its main purpose was the physical 'reconditioning' of men whose bodies were judged 'soft' as the result of idleness and poor nutrition. Of course, we can see this as in itself a panoply of ideas, associated with a set of instructional practices which involved living in a standardised space, at a considerable distance from one's home, and undergoing a regime of sustained heavy manual labour, often in difficult climatic conditions, supplemented by a diet rich in protein and energy plus regular medical attention. While work in the 'open air' was seen as desirable, it was not justified on anti-urban grounds, not least because so many long term unemployed men came from the villages and small towns of the mining regions, rather than from London or Manchester. This was not a particularly subtle set of pedagogic practices, and it was clearly directed more towards the body than the mind.

Work played a central role in all three cases discussed here. Discursively, it formed a continuing thread within the rhetorical presentation of each camping movement. Physically, as well as ideologically, work made bodies. Socially, work represented a means of belonging and a basis for social solidarity. Educationally, work was presented either as the means by which men achieved a new body that belonged to, and was part of the creation of, a new world or, as in the Ministry of Labour camps, as something which could recreate a working man's body that corresponded to the ideal physically healthy form of the productive worker. Seen as a liminal practice, work in the open air allowed the trainee to test and try out a new identity, whether as the backbone of a new social order or as a 'hardened' and productive worker. In either case, the new identity was gendered: 
the hardened worker's body was a male body. The transition at work was therefore one of entry, or re-entry, into full adult manhood.

Camping movements for adults, and particularly work camps, therefore show a rather different dynamic from those organised for children. Camps for children were primarily conceived as a release from city life, and presented usually as a kind of holiday experience. Work was more or less absent, unless it was concerned with the everyday maintenance of camp life. Teachers were encouraged to disguise school work, where it formed any part of a camp's purpose, as merely another leisure activity. Where adults are concerned, there is no reason for assuming that camping movements were inherently anti-urban, or even designed to offer a relief from urban life. In the cases discussed here, the antiurban element is explicit and articulated theoretically as part of a political critique of contemporary society in two cases. In the third case, 'roughing it' in a remote rural area was valued because it was seen as easing the return to 'normal' urban employment, not as providing an alternative. Ideals of the land in Britain, and England in particular, may have provided a resource in thinking critically about the status quo, but their ability to inspire alternative worlds was limited.

\section{Notes}

1. See D. Macleod, Building Character in the American Boy: The Boy Scouts, YMCA and their Forerunners, 1870-1920 (Madison, 1983), pp. 234-45; M. Rosenthal, The Character Factory: Baden-Powell and the Origins of the Boy Scout Movement (London, 1986).

2. F. J. Hemmings and A. Lates Stevenson, 'School Camping', in The Teachers' Guide: A Practical Treatise Written by Specialists (London, 1930), pp 227-69.

3. B. Henriques, Club Leadership (Oxford, 1933), pp. 140-1.

4. D. Pomfret, 'The City of Evil and the Great Outdoors: The Modern Health Movement and the Urban Young, 1918-1940', Urban History, 28 (2001), 405-27.

5. The Times, $13^{\text {th }}$ September 1918.

6. Ina Zweiniger-Bargielowska, Managing the Body: Beauty, Health and Fitness in Britain, 1880-1939 (Oxford, 2010), pp. 281-2

7. See the analysis in K. Cupers, 'Governing through Nature: Camps and Youth Movements in Interwar Germany and the United States, Cultural Geographies, 17 (2008), 173-205

8. The notion of liminality is drawn from the anthropology of social transitions, as explored in V. Turner, The Ritual Process: Structure and Anti-Structure (New York, 1996), p. 95.

9. J. Field, 'Exporting People of British Stock: Training and Emigration Policy in Interwar Britain', SCUTREA conference 2010, available at http://tinyurl.com/3obrtjq .

10. Report of the Oversea Settlement Committee (OSC) for the year ended $31^{\text {st }}$ December 1928, HMSO, London, 1929, p. 5.

11. Bowers to A. W. Hurst, Treasury, $12^{\text {th }}$ December 1928, National Archives (NA) T161/902.

12. Parliamentary Debates, $14^{\text {th }}$ April 1927.

13. London Unemployed Fund. Preliminary Statement (London, 1905), p. 36; G. Lansbury, My Life (London, 1928), p. 147.

14. For example, Parliamentary Debates, $5^{\text {th }}$ August $1925,14^{\text {th }}$ April 1927.

15. G. D. H. Cole, The Next Ten Years in British Social and Economic Policy (London, 1929), pp. $48-55$.

16. Ministry of Labour Circular Minute 58/1932, $1^{\text {st }}$ June 1932, NA LAB2/1775/SE774.

17. Labour Emergency Expenditure Committee. Proposal, $21^{\text {st }}$ December 1928, NA T161/902.

18. Dunoon Herald and Cowal Advertiser, $2^{\text {nd }}$ November 1934. 
19. E. Rendle, 'Social and Economic Changes in Forestry in the Inter-war Years', Scottish Woodland History Discussion Group Notes, 8 (2003), 30.

20. Passmore to Barlow, $9^{\text {th }}$ November 1932, NA LAB18/31.

21. Labour Emergency Expenditure Committee. Proposal, 23 $3^{\text {rd }}$ March 1933, NA LAB18/31.

22. G. Anderson to Passmore, $23^{\text {rd }}$ June 1933, NA LAB18/31.

23. Passmore to Allen, $11^{\text {th }}$ January 1933, NA LAB18/31.

24. K. K. Patel, Soldiers of Labor: Labor Service in Nazi Germany and New Deal America, 19331945 (New York, 2005), pp. 194 and 302.

25. UABNI. Memorandum by the Chairman on Training, $1^{\text {st }}$ January 1935, Public Records Office of Northern Ireland, LAB/5/2.

26. Blackshirt, $13^{\text {th }}$ March 1937.

27. Blackshirt, $6^{\text {th }}$ November 1937.

28. See W. H. G. Armytage, Heavens Below: Utopian Experiments in England, 1560-1960 (London, 1961).

29. D. Prynn, 'The Woodcraft Folk and the Labour Movement, 1925-70', Fournal of Contemporary History, 18 (1983), 79-95.

30. J. J. Mallon, 'A “Peace Army” Takes the Field', Labour Magazine, 11 (1933), 403.

31. A. T. Westlake, 'History of the Order of Woodcraft Chivalry from its Origins until 1934', in A. T. Westlake and others, An Outline History of the Order of Woodcraft Chivalry, 1916-1976 (London, 1979), pp. 10-15.

32. D. Edgell, The Order of Woodcraft Chivalry, 1916-1949 as a New Age Alternative to the Boy Scouts (Lewiston NY, 1993), Volume 1, p. 214

33. Edgell, Order of Woodcraft Chivalry, Volume. 1, p. 227.

34. Cited in Edgell, Order of Woodcraft Chivalry, Volume 2, p. 457.

35. Westlake, 'History of the Order of Woodcraft Chivalry', pp. 21-3

36. Edgell, Order of Woodcraft Chivalry, Volume 2, pp. 463-4.

37. Children's Newspaper, $20^{\text {th }}$ August 1932; D. Edgell, Order of Woodcraft Chivalry, Volume 2, p. 471.

38. Daily Express, $5^{\text {th }}$ September 1932.

39. Daily Mirror, $19^{\text {th }}$ April 1934.

40. Norman Glaister to E. H. E. Havelock, Development Commission, $15^{\text {th }}$ March 1937, NA $\mathrm{D} / 4 / 372$.

41. Edgell, Order of Woodcraft Chivalry, Volume 2, pp. 463-4.

42. A Technique for the Expansion of Rural Life. Memorandum from Grith Fyrd Camps to HM Treasury, August 1933, NA LAB23/19.

43. J. Norman Glaister, 'Grith Pioneers - Some Experiences of a Community', Community in Britain: A Survey of Community Thought and Activity Compiled Mainly from Addresses Given at the Bath and London Conferences in 1937 (Ashton Keynes, 1938), p. 48.

44. Daily Express, $29^{\text {th }}$ June 1932.

45. Technique for the Expansion of Rural Life, August 1933, NA LAB23/19.

46. H. E. P. Bunday, General Secretary Grith Fyrd Camps, to F. Malcolm Stewart, Commissioner for Distressed Areas, $3^{\text {rd }}$ March 1936, NA LAB23/19.

47. D. Bradshaw, The Hidden Huxley: Contempt and Compassion for the Masses, 1919-1937 (London, 1994), pp. 238-9.

48. For examples, see Workers' Educational Association, Thirty-Second Annual Report for the Year Ended 31 $1^{\text {st }}$ May, 1935, p, 68; Thirty-Third Annual Report for the Year Ended 31 ${ }^{\text {st }}$ May, 1936, p. 75; 34th Annual Report for the Year Ended 31 ${ }^{\text {st }}$ May, 1937, p. 73.

49. Keeling to Malcolm Stewart, Distressed Areas Fund, $21^{\text {st }}$ November 1934, NA LAB23/19; Note, C. M. Ryan, $1^{\text {st }}$ March 1935, NA LAB23/19.

50. D. Wills, The Hawkspur Experiment: An Informal Account of the Training of Wayward Adolescents (London, 1967). 
51. The most comprehensive treatment to date is M. Jefferies and M. Tyldesley, eds, Rolf Gardiner: Folk, Nature and Culture in Interwar Britain (Farnham, 2010).

52. R. Moore-Colyer, 'A Northern Federation? Henry Rolf Gardiner and British and European Youth', Paegagogica Historica, 39:3, 313-8.

53. C. Bearman, 'The Sorcerer's Apprentice: Mary Neal and Rolf Gardiner', The Morris Dancer, 4 (2009), accessed on 12/6/11 at www.themorrisring.org/themorrisdancer/4_1/bearman.html.

54. North Sea and Baltic, Harvest 1937.

55. M. Jefferies, 'Rolf Gardiner and German Naturism', in M. Jefferies and M. Tyldesley, eds, Rolf Gardiner, p. 57.

56. ICGC, Summer Vacation Camp: September 1930, accessed on 21/4/2010 at http://www.icgcarchive.co.uk/1930s/documents/1930_summer_camp_report.pdf.

57. North Sea and Baltic, Spring 1936.

58. North Sea and Baltic, Spring 1935.

59. North Sea and Baltic, Spring 1935.

60. Untitled report, Informant B.2f, $4^{\text {th }}$ July 1939, Notes and comments for attention $3^{\text {rd }}$ July 1940, NA KV2/2245.

61. R. Moore-Colyer, 'Rolf Gardiner, English Patriot and the Council for the Church and Countryside', Agricultural History Review, 49 (2001), 189.

62. R. Gardiner, The Second Coming and Other Poems, 1919-1921 (Vienna, 1921), p. 34 .

63. G. Boyes, 'Potencies of the Earth: Rolf Gardiner and the English Folk Dance Revival', in M. Jefferies and M. Tyldesley, eds, Rolf Gardiner, pp. 70-71.

64. North Sea and Baltic, Autumn 1932.

65. R. Gardiner, 'The Triple Function of Work Camps and Work Service in Europe', North Sea and Baltic, Harvest 1937.

66. K. K. Patel, Soldiers of Labor, pp. 194-7.

67. Gardiner, 'Triple Function', 28.

68. Memorandum on the development of a Residential Centre for Social Education at Springhead, no date [?1934?], Pennyman Papers, Teesside Archives U/PEN/11/30.

69. North Sea and Baltic, Harvest 1937.

70. Students' Work Camps in North Yorkshire, 1934, Pennyman Papers, Teesside Archives $\mathrm{U} / \mathrm{PEN} / 11 / 32$.

71. North Sea and Baltic, Midwinter 1937.

72. Bene to Auslandsorganisation of the NSDAP, $30^{\text {th }}$ August 1934, NA KV2/2245.

73. North Sea and Baltic, Autumn 1932.

74. North Sea and Baltic, September 1933.

75. Memorandum on the Development of a Residential Centre for Social Education at Springhead, no date [?1934?], Pennyman Papers, Teesside Archives U/PEN/11/30.

76. Springhead Work Camps: What they are and how to join them, no date, Pennyman Papers, Teesside Archives U/PEN/11/30.

77. North Sea and Baltic, September 1933.

78. North Sea and Baltic, Autumn 1939.

79. Springhead Ring News Sheet, Winter Solstice 1938.

80. Springhead Ring News Sheet, September 1939.

81. Fourth Cleveland Work Camp 1933, Teesside Archives U/PEN/11/28; Northern Echo, $19^{\text {th }}$ November 2009.

82. Unsigned note, no date [1939-40], NA KV2/2245.

83. R. J. Moore-Colyer, 'Rolf Gardiner, English Patriot', 187-209.

84. Director-General to liaison office for Central Africa, 10/10/49, NA KV2/2245.

85. http://www.springheadtrust.co.uk/, accessed 22/10/11. 
86. N. Götz and K. K. Patel, 'Facing the Fascist Model: Discourse and the Construction of Labour Services in the USA and Sweden in the 1930s and 1940s', Fournal of Contemporary History, 41:1 (2006), 65-8; L. S. MacDowell, 'Relief Camp Workers in Ontario during the Great Depression of the 1930s', Canadian Historical Review, 76:2 (1995), 205-28; Patel, Soldiers of Labor. 